\title{
Environment as a Breast Cancer-Causing Factors in Urban Women in Indonesia
}

\author{
Ika Dharmayanti ${ }^{1}$, Khadijah Azhar ${ }^{1} \&$ Dwi Hapsari Tjandrarini ${ }^{1}$ \\ ${ }^{1}$ National Institute of Health Research and Development, Ministry of Health, Jakarta, Indonesia \\ Correspondence: Ika Dharmayanti, National Institute of Health Research and Development, Jl.Percetakan Negara \\ 29, Jakarta 10560, Indonesia. Tel: 62-815-879-7085. E-mail: ika_skm@yahoo.com
}

Received: June 15, 2020 Accepted: July 23, 2020 Online Published: September 9, 2020

doi:10.5539/gjhs.v12n11p45 URL: https://doi.org/10.5539/gjhs.v12n11p45

\begin{abstract}
Environmental influence is one of the important factors in breast cancer incidence because residential and work environments may be potential for breast cancer outcomes. This study aimed to determine residential and workplace environments with the occurrence of women breast cancer in urban areas in Indonesia. This study used data from Non-Communicable Disease (NCD Research) in 2016 which covered 34 provinces in Indonesia. There were 38,790 people to measure the occurrence of breast cancer in women aged 25-64 years. The sample was women who were willing to be interviewed and to conduct clinical breast examinations (Sadanis). The analysis was aimed at finding out the correlation between exposure, residential environment, and workplaces with the occurrence of breast tumor/cancer. The results showed that the risk of breast cancer in women who worked in risky workplaces from the normal state was 1.96 times higher than women who worked in non-risky workplaces $(\mathrm{OR}=1.96 ; 95 \% \mathrm{CI}=1.41$ to $2.7 ; \mathrm{p}<0.001)$. Suspected of tumor/cancer in the residential areas are inversely proportional to those not living close to the mining location $(\mathrm{OR}=0.86 ; 95 \% \mathrm{CI}=0.77$ to $0.97 ; \mathrm{p}<0.001)$. These findings suggest the important role of the environment in breast cancer incidence. Therefore, it is recommended to apply a healthy lifestyle, both physically and spiritually, and provide regular health screening.
\end{abstract}

Keywords: breast cancer, environment, suspected breast tumor/cancer, women

\section{Introduction}

Cancer is one of the leading causes of death worldwide. The World Health Organization (WHO) estimated that the growth of new cases of cancer would increase by $70 \%$ in the next two decades (Center for Data and Information et al., 2015). Around 14.1 million cancer cases occurred in 2012 and around 8.2 million deaths worldwide (Torre et al., 2015). In 2018, cancer cases increase to 18 million cases globally, killing almost 9.6 million people (IARC, 2018). In other words, almost one in six deaths was caused by cancer.

Breast cancer is the most common type of cancer among women (25.2\%) (IARC, 2018). According to IARC 2018, the estimation of women breast cancer during 2018 was 2.1 million with a mortality rate of 626,679 people. Women breast cancers occur in 154 countries with most cases occurring in Asia (43.6\%), Europe (25\%), and North America (12.6\%) (Bray et al., 2018). Although the risk of breast cancer incidence is mostly found in development and high economies countries, the highest mortality was in low and middle-income countries (IARC, 2018).

Basic Health Research (Riskesdas) 2013 reported the prevalence of cancer in Indonesia was 1.4 per-mile (\%o) or an estimated 347,792 people, with the highest prevalence in Yogyakarta (4.1\%) (MOH RI, 2013). Breast cancer is the second-highest prevalence of cancer $(0.5 \%)$ after cervical cancer $(0.8 \%)$ with 61,682 sufferers (MOH RI, 2013). Indonesian health profile 2018 data stated that after cervical cancer, the prevalence of breast cancer is the second highest type of cancer in women in Indonesia. The result of early detection of breast cancer in women aged 30-50 years was 16,956 had breast tumors and 2,253 suspicious of breast cancer (MOH RI, 2019). The coverage of early detection of breast cancer is highest in West Java 24.4\%, followed by Central Java 12.8\%, and Bali 11.3\%.

During 2010-2015, Dharmais Cancer Hospital in Indonesia recorded the number of new diseases and the deaths due to breast cancer continue to increase, with a proportion of about $40 \%$ of all cancer cases in the Hospital (RI, 2016). The main problem of breast cancer in Indonesia is that most of the patients who come for treatment are already in stage III to IV (advanced stage). This condition should be controlled by making early detection of breast self-examination (BSE) or using more accurate detection by mammography.

Cancer is a genetic mutation from normal to abnormal cells through several stages, generally from pre-cancerous 
lesions to tumors. This illness requires a long process to turn into cancer cells in the human body. These cells grow and divide abnormally and uncontrollably then spread to other organs causing death (World Health Organization, 2002). Under normal circumstances, cell division occurs if there are unused cells that have died and damaged. While cancer cells continue to divide even they are not needed by the body, as a result, cell accumulation will damage normal tissue and disrupt the organs it occupies (American Cancer Society, 2015). There are two types of tumors, namely benign tumors and malignant tumors. Benign tumors have limited growth characteristics, have sheaths, and can be removed from the body as a whole through surgery, so the sufferers can be recovered completely. Meanwhile, malignant tumors can enter the surrounding tissue and cancer cells can be found in the growth of the tumor (World Health Organization, 2002).

Breast cancer is a malignancy originating from glandular cells, glandular channels, and supporting breast tissue (MOH RI, 2015). Breast cancer can cause lumps, but some types have non-painful lumps or masses. Most breast lumps are benign (non-cancerous) and are not cancer. Breast lumps are abnormal growths of cells in the breast but do not spread to other organs and do not cause deaths. Some breast lumps can be growth to breast cancer (American Cancer Society, 2015).

Breast cancer risk factors are multi-factorial with many factors that are related to one with another. Several factors are thought to have a large influence on the occurrence of breast cancer. Elsharkawy stated that breast cancer risk factors are family history, genetic predisposition, personal history of breast cancer, lobular carcinoma in situ, benign breast disease, breast density, endogenous hormone levels, menstrual cycles, pregnancy and breastfeeding, and bone mineral density. Risk factors include personal lifestyles, such as hormonal use, obesity and weight gain, physical activity, diet, alcohol, and tobacco. Other risk factors are due to exposure radiation, diethylstilbestrol, environmental pollutants, and occupational exposure (Elsharkawy, 2014).

The risk of developing breast cancer increases as woman ages until menopause, then the risk decline in older age. Breast cancer is not common in younger women (less than 20 years) and older women (more than 80 years) (Autier et al., 2010). Other studies found that women 45 years of age and older are at high risk of suffering from breast cancer (Pranjić et al., 2015). Several factors are believed to influence such as geographical location (solar ultraviolet exposure), early age of menarche (under 12 years), low parity, lactation, obesity, genetics, and the family history of breast cancer (Laden \& Hunter, 1998). The increased cases of cancer or suspected cancer are affected more by personal lifestyle and environmental factors compared to genetic factors, namely smoking, alcohol and physical activity, and environmental influences (radiation, pollution, and infection) (Hosseinzadeh et al., 2014).

Some research has shown that the physical environment is associated with an increased risk of breast cancer (Fenton \& Birnbaum, 2015; Pranjić et al., 2015; Siddique et al., 2016). Other studies showed an increased risk of breast cancer in women exposed to ionizing and non-ionizing radiation, polycyclic aromatic hydrocarbons (PAH), pesticides, and metal industry (Fenga, 2016). A higher risk of breast cancer was also found among women working on agriculture, forestry, health, and production who started the jobs at least 20 years ago (Ji et al., 2008). Other factors that have been identified as environmental risk factors for breast cancer, such as night lighting (impaired melatonin secretion), hormone disruptors (phthalates), environmental pollution (hydrocarbons, organochlorines), and work exposures (chemicals, radiation) (Picciotto et al., 2012). The contribution of a chemical/physical substance in the environment to breast cancer depends on its duration and dose of exposure. As cases of breast cancer increase, the Indonesian government needs to increase public awareness in recognizing cancer risk factors. Thus, this study aimed to describe the correlation between the residential and work environment with the occurrence of tumors and breast cancer through demographic analysis to find out the appropriate preventive measures.

\section{Method}

The data source used was the Non-communicable Disease Research (NCD Research) conducted by The National Institute Health Research and Development Agency (NIHRD) in 2016. The data usage permit was based on the NIHRD statement letter number 15051703-048.

This community-based survey collected data on breast and cervical cancer with a cross-sectional design. The study was conducted in 70.000 households in 1400 census blocks of 76 districts/cities in 34 provinces in Indonesia. This analysis used a sub-sample with criteria were women aged 25-64 years and had the result of interviews and clinical breast examination complete. A total of 38.790 respondents provided information at the national levels.

The results of breast examination were grouped into three categories, namely cancer, suspected cancer/tumor, and normal. Demographic factors were analyzed to get information on breast cancer cases characteristics such as age group, marital status, education, occupation, and economic status. The economic status was obtained based on the wealth index, which consisted of the main sources of drinking water, fuel for cooking, and ownership of sanitary 
facilities, lighting source, vehicles, gas tube, and electronic goods which in turn form five quintile categories.

The environmental factors examined in this study were their residences, such as mining areas or industrial estates. The types of mining that were asked in this study were tin mining, illegal gold mining, coal mining, and others. Meanwhile, the main industrial materials asked in this research were (1) leads used in pipe, paint, cable, bullet, radiation protection, petroleum, and other industries, (2) phthalates in plastics, cosmetics, perfumes, nail polish, shampoo, building equipment, ceramics, cleaning tools, cars, and other industries, and (3) aluminum in deodorant and antiperspirant industries.

The type of occupation that was considered at risk of causing tumors and breast cancer were an operator of a radiation/x-ray machine, an employee in the field of atomic power in health institutions (hospitals, health centers, and polyclinics), National Nuclear Energy Agency of Indonesia (BATAN), and the like. The participants were asked whether they were working or having worked at mining sector or in the production sector of the industry, working at (1) industries of weed or pest exterminators (herbicides/pesticides) such as paraquat/ Gramoxone, glyphosate/ Roundup, and so on, (2) industries of insecticides such as bendiocarb/ Ficam, lambda-cyhalothrin/Icon, deltamethrin/ K-othrine, etofenprox/ Vectron, bifenthrin/ Bistar, alfa cypermethrin/ Fendona, (3) illegal tin mines, (4) tin-based industries namely for handicrafts, jewelry or kitchenware (5) industries of lead-based materials used for pipe, paint, cable, bullet, radiation protection, oil drilling equipment, and so on (6) illegal gold mining, (7) industries of phthalates used for plastics, cosmetics, baby devices, building devices, ceramics, tools cleaners, cars, and so on.

For analysis, a multinomial logistic regression test was performed to analyze the correlation of one of several independent variables with a non-dichotomous/non-binary categorical dependent variable (David \& Lemeshow, 2000).

\section{Results}

Table 1 shows a description of the characteristics of women in the 25-64-year age group. Most women were married/ ever married, had elementary to high school education, were housewives and did not work, and mostly had low and high economic conditions.

In this analysis, the group suffering from breast cancer was individuals who had been diagnosed with breast cancer or had had surgery on the breast caused by cancer (malignant tumor). Most of them were unmarried and/or had tertiary education. The same thing is seen in the group with suspected tumors/cancer. Most of them were not married, had tertiary education, and/ or were working in the formal sectors.

Table 1. Prevalence of Tumors or Breast Cancer based on Demographic Characteristics

\begin{tabular}{|c|c|c|c|c|c|c|c|c|}
\hline \multirow{3}{*}{ Characteristics } & & \multicolumn{6}{|c|}{ Breast examination results } & \multirow{3}{*}{$\begin{array}{l}\text { Total } \\
\mathrm{n}\end{array}$} \\
\hline & & \multicolumn{2}{|c|}{ Cancer } & \multicolumn{2}{|c|}{ Suspected tumor/cancer } & \multicolumn{2}{|l|}{ Normal } & \\
\hline & & $\mathrm{n}$ & $\%$ & $\mathrm{n}$ & $\%$ & $\mathrm{n}$ & $\%$ & \\
\hline \multirow{2}{*}{ Age (Year) } & $40+$ & 251 & 1.1 & 1,801 & 8.2 & 20,197 & 90.6 & 22,249 \\
\hline & $<40$ & 154 & 1.1 & 1,394 & 8.5 & 14,993 & 90.4 & 16,541 \\
\hline \multirow{2}{*}{ Marital status } & Single & 11 & 2.8 & 54 & 16.0 & 387 & 81.2 & 452 \\
\hline & Married/ever married & 394 & 1.1 & 3,141 & 8.2 & 34,803 & 90.7 & 38,338 \\
\hline \multirow{2}{*}{ Education } & Elementary school - high school & 331 & 1.0 & 2,779 & 8.1 & 31,406 & 90.0 & 34,516 \\
\hline & Tertiary & 74 & 1.9 & 416 & 10.5 & 3,784 & 87.6 & 4,274 \\
\hline \multirow{3}{*}{ Occupation } & Not working & 256 & 1.2 & 1,972 & 7.8 & 22,405 & 91.0 & 24,633 \\
\hline & Formal worker & 113 & 1.2 & 847 & 9.7 & 8,410 & 89.2 & 9,370 \\
\hline & Non-formal worker & 36 & 0.7 & 376 & 8.6 & 4,375 & 90.7 & 4,787 \\
\hline \multirow{3}{*}{ Economic status } & Low & 223 & 1.4 & 1,406 & 8.6 & 14,920 & 90.0 & 16,549 \\
\hline & Middle & 66 & 1.0 & 514 & 8.3 & 5,686 & 90.7 & 6,266 \\
\hline & High & 116 & 0.8 & 1,275 & 8.1 & 14,584 & 91.0 & 15,975 \\
\hline Total & & 405 & 1.1 & 3,195 & 8.4 & 35,190 & 90.5 & 38,790 \\
\hline
\end{tabular}

Based on Figure 1, it can be seen that the percentage of cancer sufferers who lived in mining locations is greater 
than that of cancer sufferers who did not live in mining locations. Likewise, the women who work at risk sites had higher percentages of having breast cancer compared to those who were not working or did not work in risky places. In contrast to the group suspected of having tumors/cancers, the percentage is seen high for women who did not live in mining locations. There is almost no difference in the percentage of women diagnosed with suspected tumor/cancer when viewed based on their place of work.

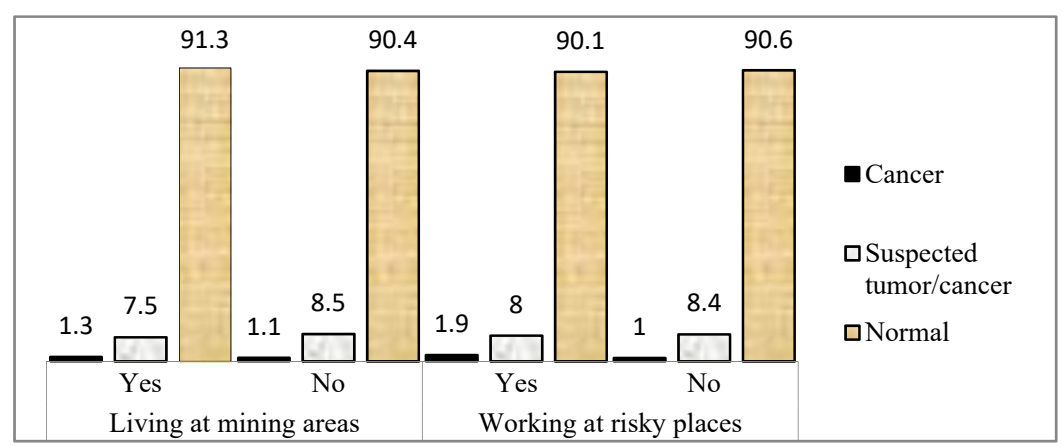

Figure 1. Prevalence of Tumors or Breast Cancer based on Residence and Workplace

The results in Table 2 show that the opportunity of unmarried women to experience breast cancer from the normal state (diagnosed neither with cancer nor suspect tumor/cancer) was 2.84 times higher than that of women who were married or ever married, with the presence of other factors. Meanwhile, the opportunity of unmarried women diagnosed with a suspected tumor or breast cancer from the normal state (diagnosed neither with cancer nor suspected tumor/cancer) was 1.96 times higher than that of women who were married or ever married, with the presence of other factors. The opportunity for women with low economic status to suffer from breast cancer from the normal state was 1.5 times higher than that of women with high economic status, after controlling with other factors. The opportunity of women working in risky workplaces to suffer breast cancer from the normal state was 1.96 times higher than that of those who worked in the non-risky workplace, after controlling with other factors. A significant correlation but the risk is protective is seen in the factors of education, employment, and residence.

Table 2. Multinomial Logistic Regression Test Results

\begin{tabular}{|c|c|c|c|c|c|c|c|c|}
\hline \multirow{3}{*}{ Characteristics } & \multicolumn{8}{|c|}{ Breast examination results } \\
\hline & \multicolumn{4}{|l|}{ Cancer } & \multicolumn{4}{|c|}{ Suspected tumor/cancer } \\
\hline & OR & $95 \% \mathrm{C}$ & & Sig & OR & $95 \% \mathrm{CI}$ & & Sig \\
\hline \multicolumn{9}{|l|}{ Age (year) } \\
\hline $40+$ & 1.172 & 0.966 & 1.423 & 0,107 & 0.990 & 0.920 & 1.065 & 0,787 \\
\hline$<40$ & 1.000 & & & & 1.000 & & & \\
\hline \multicolumn{9}{|l|}{ Marital status } \\
\hline Single & 2.836 & 1.788 & 4.499 & 0,000 & 1.955 & 1.592 & 2.399 & 0,000 \\
\hline Married/ever married & 1.000 & & & & 1.000 & & & \\
\hline \multicolumn{9}{|l|}{ Education } \\
\hline Elementary school - high school & 0.587 & 0.444 & 0.776 & 0,000 & 0.852 & 0.756 & 0.960 & 0,008 \\
\hline Tertiary & 1.000 & & & & 1.000 & & & \\
\hline \multicolumn{9}{|l|}{ Occupation } \\
\hline Not working & 1.060 & 0.794 & 1.413 & 0,694 & 0.802 & 0.718 & 0.897 & 0,000 \\
\hline Non-formal & 0.723 & 0.512 & 1.021 & 0,066 & 0.895 & 0.791 & 1.013 & 0,079 \\
\hline Worker & 1.000 & & & & 1.000 & & & \\
\hline
\end{tabular}




\begin{tabular}{lllllllll}
\hline Economic status & & & & & & & & \\
Low & 1.495 & 1.197 & 1.868 & 0,000 & 1.031 & 0.951 & 1.118 & 0,461 \\
Middle & 1.110 & 0.811 & 1.518 & 0,514 & 1.006 & 0.902 & 1.122 & 0,911 \\
High & 1.000 & & & & 1.000 & & & \\
\hline $\begin{array}{l}\text { Living in mining areas } \\
\text { Yes, ever }\end{array}$ & 0.946 & 0.707 & 1.265 & 0,707 & 0.862 & 0.767 & 0.968 & 0,012 \\
$\quad$ Never & 1.000 & & & & 1.000 & & & \\
\hline $\begin{array}{l}\text { Working at risky places } \\
\text { Yes }\end{array}$ & 1.955 & 1.413 & 2.703 & 0,000 & 1.048 & 0.902 & 1.219 & 0,540 \\
No & 1.000 & & & & 1.000 & & & \\
\hline
\end{tabular}

Note. 95\% CI: Confidence Interval; Normal state (no-cancer) as reference.

\section{Discussion}

The results of the study show that women in urban areas who are not married, highly educated, working women, not living in mining areas, and working at risky environments have a greater risk of suffering from breast cancer or suspected tumor/cancer.

Some studies show several risk factors are contributing to the development of breast cancer and one of which is age as the main factor (Desantis et al., 2016; Sihombing \& Sapardin, 2014). In general, breast cancer is found in women over the age of 60 years, and around $10-15 \%$ occurs at the age of fewer than 45 years. As the age rise, women more susceptible to breast cancer. One study found that the risk for women aged over 40 years for experiencing breast tumors was 8.82 times higher than that of women aged less than 40 years (Sihombing \& Sapardin, 2014).

But in this study, it was found that women aged 40 years and over were at risk of breast cancer from the normal state by 1.2 times, even though these results are not statistically significant. This might happen because the first-time suffering from cancer was not known in this study, while the process of cancer requires stages and time. Accumulation of prolonged exposure to carcinogens such as chemicals usually takes many years before cells begin malignantly. As a result, breast cancer is frequently diagnosed at an older age. To avoid this condition, the Ministry of Health recommends breast self-exam (BSE/Sadari) and Sadanis to detect breast cancer earlier, so the impact of this disease can be minimized (MOH RI, 2015). Sadari is a technique to examine your breast tissue for any visual or physical changes. While Sadanis screening is performed by a health professional, at least every three years starting at age 20 and every year at aged 40 and older.

Current data show that marital status is associated with the risk of breast cancer. Several studies have shown that marital status is a contributing factor in improving the quality of life of breast cancer sufferers and decreasing the risk of more extensive or severe disease conditions (Liu et al., 2019; Martínez et al., 2017; Osborne et al., 2005). Even after the treatment to control the stage of cancer, the risk of death in unmarried women is greater than married women (Osborne et al., 2005).

Based on the result, the OR value of low education people on breast cancer is 0.587 . This means that the risk of breast cancer based on education is reversed from the hypothesis. So, the results of the analysis show that higher education has a greater risk of developing cancer or suspected tumor/cancer from the normal state of 1.7 times and 1.2 times, respectively. This is probably due to the increasing number of women with higher education who work and occupy high positions, thus experiencing stress in the workplace. Stress caused by work problems can lead to biochemical, physiological, and behavioral changes that can burden a person and threaten their health, such as cancer, diabetes, hypertension, and mental health disorders in workers (International Labour Organization, 2016).

Based on the type of work, a formal worker has a greater risk than other workers at 1.25 times for being diagnosed with suspected cancer/tumor. This means that housewives do not have the risk of being exposed to carcinogens that can occur at work. In line with research conducted in Turkey that educated women more susceptible to breast cancer than housewives, besides screening of this disease is also below $50 \%$ (Yilmaz et al., 2011).

The results can be assumed that the education level will affect their type of work. Someone with higher education will tend to get a formal job but may increase the risk of cancer because of exposure to carcinogens in the workplace and stress due to high workloads (Brophy et al., 2012; International Labour Organization, 2016). 
The tendency of women with low economic status to suffer breast cancer from the normal state is 1.5 times higher than women with high economic status. According to the American Cancer Society (ACS), people of lower economic backgrounds are more at risk of suffering cancer due to their unhealthy behaviors which increase the risk of cancer (American Cancer Society, 2017) like smoking, consuming unhealthy foods, eating fewer fruits and vegetables, and lacking exercise.

The type of living environment, whether or not close to the mining location, apparently does not affect the occurrence of breast cancer or suspected tumor/cancer. Even the results of the analysis are inversely proportional to the theory, saying that houses that are not located in the mining area can trigger suspected tumor/cancer at 1.2 times compared to the normal state. This is in line with the previous results that women who work as housewives have a lower risk of cancer than female workers (Yilmaz et al., 2011). The absence of exposure to women who lived close to mining is possible because this study only captured conditions in urban areas so that there was a small possibility of exposure to mining materials in residential locations.

In this study, women who worked in a risky working environment at risk of experiencing cancer 1.96 times higher, compared to the normal state. This shows that working in an unhealthy workplace due to carcinogenic substances in the workplace also increases the risk of breast cancer and causes at least 152,000 deaths annually (Brophy et al., 2012; Center for Data and Information et al., 2015; Karima \& Wahyono, 2013). Several studies have shown an increase in the incidence of breast cancer in women exposed to the main ingredients of the chemical industry such as polycyclic aromatic hydrocarbons (PAH), some solvents, pesticide ingredients, and metals (Engel \& Rasanayagam, 2015; Fenga, 2016; International Agency for Research and Cancer \& World Health Organization, 2012). Besides, the risk of breast cancer is also found in women who work in the pharmaceutical, cosmetics, hairdresser, radiation/x-ray machine, cleaning products, car operators, and so on (Brophy et al., 2006; Engel \& Rasanayagam, 2015; Ji et al., 2008; Pranjić et al., 2015). Therefore, every worker who may be potentially exposed to carcinogenic materials must determine how to protect themselves with appropriate engineering and administrative controls, safe work practices, and personal protective equipment (International Labour Organization, 2013).

This research has several limitations. The first is NCD Research does not have related data in terms of when a person has cancer or suspected tumor/cancer, so we cannot identify the length of time a woman has to suffer from cancer or suspected tumor/cancer. The second is the data source only describes the urban area in Indonesia, so it is less able to describe the condition of the mining environment which is generally located in rural areas. The third limitation is we are not considering genetic factors from the family in causing cancer because this study focused on risky workplaces.

Therefore, if a person has breast cancer, he/she must immediately visit a health service and take medication and do a healthy lifestyle. Besides, efforts to prevent breast cancer also need to be carried out as recommended by the Minister of Health to carry out regular health checks, eliminate cigarette smoke, do physical activity regularly, do a healthy diet with balanced calories, get enough rest, and manage stress (RI, 2016).

\section{Conclusions and Recommendations}

In conclusion, this study confirms that there are significant correlations and risk value, namely the marital status, economic status, and risky workplace. Therefore, to prevent the occurrence of breast cancer, the community should implement healthy behaviors and know cancer-causing factors to minimize the possibility of breast cancer occurrence. The role of the work environment that is physically and mentally healthy can reduce the occurrence of cancer.

Applying a healthy lifestyle in the family and workplace and doing regular Sadari and Sadanis screening is essential to prevent breast cancer. Reducing exposure to carcinogens in the workplace by using safety protective equipment is also needs to be done. The health screening can be done at their workplaces or the NCD Integrated health service and promotions post (Posbindu PTM).

\section{Acknowledgments}

We would like to express gratitude to the Head of the National Institute of Health Research and Development, Indonesian Ministry of Health for allowing us to do this study. I would also like to extend my thanks to Management Data Laboratory, and the 2016 NCD Research team for all efforts so this article may be published.

\section{Author Contribution}

ID, KA, and DH contributed equally as the main contributor to this article. All authors read and approved the final paper. 


\section{Competing Interests Statement}

The authors declare that they have no conflict of interest.

\section{References}

American Cancer Society. (2015). About breast cancer. American Cancer Society. https://www.cancer.org/content/dam/CRC/PDF/Public/8577.00.pdf

American Cancer Society. (2017). Cancer Facts and Figures 2017. In Cancer Facts and Figures 2017. https://doi.org/10.1101/gad.1593107

Autier, P., Boniol, M., LaVecchia, C., Vatten, L., Gavin, A., Héry, C., \& Heanue, M. (2010). Disparities in breast cancer mortality trends between 30 European countries: Retrospective trend analysis of WHO mortality database. BMJ (Online), 341(7768), 335. https://doi.org/10.1136/bmj.c3620

Bray, F., Ferlay, J., Soerjomataram, I., Siegel, R. L., Torre, L. A., \& Jemal, A. (2018). Global cancer statistics 2018: GLOBOCAN estimates of incidence and mortality worldwide for 36 cancers in 185 countries. CA: A Cancer Journal for Clinicians, 68(6), 394-424. https://doi.org/10.3322/caac.21492

Brophy, J. T., Keith, M. M., Gorey, K. M., Luginaah, I., Laukkanen, E., Hellyer, D., ... \& Gilbertson, M. (2006). Occupation and breast cancer: A Canadian case-control study. Annals of the New York Academy of Sciences, 1076, 765-777. https://doi.org/10.1196/annals.1371.019

Brophy, J. T., Keith, M. M., Watterson, A., Park, R., Gilbertson, M., Maticka-tyndale, E., ... \& Luginaah, I. (2012). Breast cancer risk in relation to occupations with exposure to carcinogens and endocrine disruptors: a Canadian case-control study. Environmental Health Journal, 11(1), 1-17.

Center for Data and Information, Wahidin, M., Sabrida, H., Tehuteru, E. S., Andriana, \& Wiradinata, D. (2015, June). Cancer Situation. Bulletin of Health Data and Information.

David W, H., \& Lemeshow, S. (2000). Applied Logistic Regression.pdf(2nd ed.). Wiley Series.

Desantis, C. E., Fedewa, S. A., Sauer, A. G., Kramer, J. L., Smith, R. A., \& Jemal, A. (2016). Breast Cancer Statistics, 2015 : Convergence of Incidence Rates Between Black and White Women. A Cancer Journal for Clinicians, 66(1), 31-42. https://doi.org/10.3322/caac.21320.

Elsharkawy, A. M. (2014). Breast Cancer. In R. A. Al-Naggar (Ed.), Principles and Practice of Cancer Prevention and Control (Issue June 2014, pp. 1-38). OMICS Group.

Engel, C., \& Rasanayagam, S. (2015). Working Women and Breast Cancer : The State of the Evidence (August, pp. $1-102)$.

Fenga, C. (2016). Occupational exposure and risk of breast cancer (Review). Biomedical Reports, 4(3), 282-292. https://doi.org/10.3892/br.2016.575

Fenton, S. E., \& Birnbaum, L. S. (2015). Timing of environmental exposures as a critical element in breast cancer risk. Journal of Clinical Endocrinology and Metabolism, 100(9), 3245-3250. https://doi.org/10.1210/jc.2015-2848

Hosseinzadeh, M., Ziaei, J. E., Mahdavi, N., Aghajari, P., Vahidi, M., Fateh, A., \& Asghari, E. (2014). Risk factors for breast cancer in Iranian women: A hospital-based case-control study in Tabriz, Iran. Journal of Breast Cancer, 17(3), 236-243. https://doi.org/10.4048/jbc.2014.17.3.236

IARC. (2018). Data Breast Cancer. In Global Cancer Observatory (pp. 1-2). International Agency for Research on Cancer, World Health Organization.

International Agency for Research and Cancer, \& World Health Organization. (2012). Chemical agents and related occupations. In IARC Monographs on The Evaluation of Carcinogenic Risks to Humans: Vol. $100 \mathrm{~F}$ (Issue Mist From Strong Inorganic Acids, pp. 487-495). International Agency for Research on Cancer.

International Labour Organization. (2013). Occupational Safety and Health Safety and Health Facilities for Productivity. www.ilo.org

International Labour Organization. (2016). Workplace Stress: A Collective Challenge. In World Day For Safety and Health at Work.

Ji, B. T., Blair, A., Shu, X. O., Chow, W. H., Hauptmann, M., Dosemeci, M., ... \& Zheng, W. (2008). Occupation and breast cancer risk among Shanghai women in a population-based cohort study. American Journal of Industrial Medicine, 51(2), 100-110. https://doi.org/10.1002/ajim.20507 
Karima, U. Q., \& Wahyono, T. Y. M. (2013). Factors Related to the Occurrence of Women's Breast Cancer at the National Center General Hospital (RSUPN) dr. Cipto Mangunkusumo Jakarta in 2013. Indonesian University.

Laden, F., \& Hunter, D. J. (1998). Environmental Risk Factors and Female Breast Cancer. Annual Review of Public Health, 19, 101-123.

Liu, Y., Wang, D., Yang, Z., Ma, R., Li, Z., Suo, W., Zhao, Z., \& Li, Z. (2019). Marital status is an independent prognostic factor in inflammatory breast cancer patients: an analysis of the surveillance, epidemiology, and end results database. Breast Cancer Research and Treatment, 0123456789. https://doi.org/10.1007/s10549-019-05385-8

Martínez, M. E., Unkart, J. T., Tao, L., Kroenke, C. H., Schwab, R., Komenaka, I., \& Gomez, S. L. (2017). Prognostic significance of marital status in breast cancer survival: A population-based study. PLoS ONE, 12(5), 1-14. https://doi.org/10.1371/journal.pone.0175515

MOH RI. (2013). National Health Survey. In National Institute for Health Research \& Development. https://doi.org/10.1007/s13398-014-0173-7.2

MOH RI. (2015). Guidelines for Management of Breast Cancer. Ministry of Health.

$\mathrm{MOH}$ RI. (2019). Indonesian Health Profile 2018. Ministry of Health. http://www.depkes.go.id/resources/download/pusdatin/profil-kesehatan-indonesia/Data-dan-Informasi_Profi 1-Kesehatan-Indonesia-2018.pdf

Osborne, C., Ostir, G. V., Du, X., Peek, M. K., \& Goodwin, J. S. (2005). The influence of marital status on the stage at diagnosis, treatment, and survival of older women with breast cancer. Breast Cancer Research and Treatment, 93(1), 41-47. https://doi.org/10.1007/s10549-005-3702-4

Picciotto IH, LA, C., P, D., D, E., SK, H., KJ, H., et al. (2012). Breast Cancer and the Environment: A Life Course Approach. The National Academic Press.

Pranjić, N., Gledo, I., \& Bilić, L. M. (2015). The Most Common New Cases of Breast Cancer among the Housewives : The Some Carcinogenic Determinants. Macedonian Journal of Medical Sciences, June 2014, 10-16. https://doi.org/10.3889/oamjms.2014.059

RI, M. (2016). Breast Cancer Awareness Month. Center for Data and Information. Ministry of Health.

Siddique, S., Kubwabo, C., \& Harris, S. A. (2016). A review of the role of emerging environmental contaminants in the development of breast cancer in women. Emerging Contaminants, 2(4), 204-219. https://doi.org/10.1016/j.emcon.2016.12.003

Sihombing, M., \& Sapardin, A. N. (2014). Breast Tumor Risk Factors in Women Age 25-65 Years in Five Sub-Districts, Central Bogor District. Journal of Reproductive Health, 5(3), 175-184.

Torre, L. A., Bray, F., Siegel, R. L., Ferlay, J., Lortet-Tieulent, J., \& Jemal, A. (2015). Global cancer statistics, 2012. CA: A Cancer Journal for Clinicians, 65(2), 87-108. https://doi.org/10.3322/caac.21262

World Health Organization. (2002). National Cancer Control Programmes : Policies and Managerial Guidelines. World Health Organization.

Yilmaz, M., Guler, G., Bekar, M., \& Güler, N. (2011). Risk of breast cancer, health beliefs and screening behaviour among Turkish academic women and housewives. Asian Pacific Journal of Cancer Prevention, 12(3), 817-822.

\section{Copyrights}

Copyright for this article is retained by the author(s), with first publication rights granted to the journal.

This is an open-access article distributed under the terms and conditions of the Creative Commons Attribution license (http://creativecommons.org/licenses/by/4.0/). 